\title{
Hematological Parameters of three Strains of Local Cocks in Northern Nigeria
}

\author{
${ }^{1}$ Yasks, J. A., ${ }^{1}$ Momoh, M. O and ${ }^{2}$ Dauda, A. \\ ${ }^{1}$ Department of Animal Breeding and Physiology, University of Agriculture, Nigeria \\ ${ }^{2}$ Department of Animal Science University of Calabar P.M.B 1115 Calabar, Nigeria
}

\begin{abstract}
The study was conducted to determine the hematological parameters of three strains of the Nigerian indigenous cocks. A total of 15 sexually matured (14-18 month of age) breeders cocks comprising (5 normal feathered, 5 frizzled feathered and 5 naked neck) were used for the experiment. The study was conducted from October to December 2016 at the Teaching and Research Farm University of Maiduguri. Blood samples were collected from 9 breeder's cocks which were randomly selected 3 per genotype and used for hematological parameters examination. Hematological examination such as Packed Cell Volume (PCV), Red Blood Cell ( RBC), Haemoglobin (Hb), White Blood Cell (WBC), Mean Corpuscular Haemoglobin concentration ( MCHC), Mean Corpuscular Haemoglobin (MCH) and Mean Corpuscular Volume ( $M C V)$ showed significant $(P<0.05)$ different among breeds. Lymphocyte $(L)$ showed no significant $(P>0.05)$ different between normal feathered and frizzle feathered but there is significant difference $(P<0.05)$ with naked necked cock. Neutrophil $(N)$ showed significant $(P<0.05)$ different among the breed. Monocyte ( $M)$ and Eosinophil (E) showed no significant $(P>0.05)$ difference between normal feathered and naked neck feathered, fizzle feathered and necked neck respectively but showed significant $(P<0.05)$ difference between fizzle feathered and normal feathered respectively for $M$ and $E$. the study concluded that variation in the heamatoloical parameters between three strains of local chicken in Nigeria is due to difference in their genetic makeup.
\end{abstract}

Keywords-Haematology, Indigenous chicken, Strain.

\section{INTRODUCTION}

In many species of birds especially chicken, normal values for hematological parameters were measured and a comprehensive data base was established of their blood profile. Comparative measurements for diverse species of birds could be lead to the different statement of immune system in these birds (Simaraks et al., 2004; Pampori et al., www.ijeab.com
2007; ladokum et al., 2008 and Melesse., 2011). The Nigerian indigenous chicken breeds have been reported to have many advantageous gene complexes that could be harnessed in the development of meat or egg type chicken suitable for use in the tropics (Machebe and Ezekwe, 2004). Among these major genes are the Naked necked, Frizzled and Normal feathered (Ibe 1998). In the other hand, many researchers have evaluated normal hematological parameter of industrial and commercial hybrid chickens (Melluzzi et al., 1992; Taleb et al., 2005). Information about hematological parameters of indigenous chickens are limited therefore, this study was carried out to evaluate the haematological parameters of three strains of indigenous chickens.

\section{MATERIALS AND METHOD}

A total of fifteen (15) local breeder cocks which are sexual matured (14 - 18 months) of age, comprising three strains of indigenous cocks (5 Frizzle, 5 Normal feathered and 5 Naked Neck ) were obtained from local farmers within Borno state and were used for the experiment. The study was conducted at the Teaching and Research Farm of the Department of Animal Science, University of Maiduguri, Borno state. Maiduguri is situated within the semi arid region of Nigeria which lies within the Sahel zone of West Africa. Borno state lies within latitude $100^{\circ}$ and $140^{\circ} \mathrm{N}$ longitude $110^{\circ} 30^{\prime}$ and $140^{\circ} 45^{\prime} \mathrm{E}$. (NPC, 2006). The experimental birds were acclimatized for two weeks during which they were monitored and screened. Conventional management practice were observed throughout the study period Blood samples were collected from the wing vein of the birds using a $2 \mathrm{ml}$ disposable syringe and directly transferred into a labeled bottle containing EDTA Ethylenediamine tetra acetic acid) anticoagulant. It was immediately used for measuring the haematological parameters such as red blood cells (RBC), white blood cells (WBC), haemoglobin (HB), packed cell volume (PVC), Mean Corpuscular Volume (MCV), Mean

Page | 1139 
Corpuscular Haemoglobin (MCH), Mean Corpuscular Haemoglobin concentration (MCHC), Neutrophil (N) ,Lymphocytes (L) Monocyte (M) , EosinophlI (E) and Basopyles ( B). Data collected on blood were subjected to one way analysis of variance (ANOVA) using SPSS statistical package version 16. Separation of significant means was done using the Duncan's Multiple Range Test (Steel and Torrie, 1980).

\section{RESULTS}

Table.1: Haematological parameters in three strain of indigenous chicken

\begin{tabular}{|c|c|c|c|c|c|c|c|c|c|c|c|}
\hline Breeds & $\begin{array}{l}\text { RBC } \\
\left(\mathrm{X} 10^{9} / \mathrm{L}\right)\end{array}$ & $\begin{array}{l}\text { WBC } \\
\left(\mathrm{X} 10^{12} / 10 \mathrm{~L}\right)\end{array}$ & $\begin{array}{l}\mathrm{HB} \\
(\mathrm{g} / \mathrm{dl})\end{array}$ & $\begin{array}{l}\text { PCV } \\
(\%)\end{array}$ & $\begin{array}{l}\text { MCV } \\
\text { (fl) }\end{array}$ & $\begin{array}{l}\text { MCHC } \\
(\mathrm{g} / \mathrm{ld})\end{array}$ & $\begin{array}{l}\mathrm{MCH} \\
\text { (pg) }\end{array}$ & $\begin{array}{l}\mathrm{L} \\
(\%)\end{array}$ & $\begin{array}{l}\mathrm{N} \\
(\%)\end{array}$ & $\begin{array}{l}\mathrm{M} \\
(\%)\end{array}$ & $\begin{array}{l}\mathrm{E} \\
(\%)\end{array}$ \\
\hline $\begin{array}{l}\text { Normal } \\
\text { feather }\end{array}$ & $5.07^{\mathrm{c}}$ & $5.66^{\mathrm{b}}$ & $11.33^{\mathrm{b}}$ & $36.66^{c}$ & $7.20^{\mathrm{b}}$ & $31.24^{\mathrm{b}}$ & $22.39^{\mathrm{b}}$ & 50.66 & 30.66 & 10.33 & 8.33 \\
\hline $\begin{array}{l}\text { Frizzled } \\
\text { feather }\end{array}$ & $5.08^{\mathrm{b}}$ & $2.40^{c}$ & $11.26^{\mathrm{c}}$ & $40.00^{\mathrm{a}}$ & $7.93^{\mathrm{a}}$ & $28.47^{\mathrm{c}}$ & $22.21^{\mathrm{c}}$ & 50.66 & 30.33 & 9.33 & 9.66 \\
\hline $\begin{array}{l}\text { Naked } \\
\text { necked }\end{array}$ & $5.35^{\mathrm{a}}$ & $6.21^{\mathrm{a}}$ & $12.36^{\mathrm{a}}$ & $38.33^{\mathrm{b}}$ & $7.16^{\mathrm{c}}$ & $32.52^{\mathrm{a}}$ & $23.12^{\mathrm{a}}$ & 50.00 & 30.00 & 10.33 & 9.66 \\
\hline SEM & 0.13 & 1.15 & 0.34 & 1.09 & 2.70 & 0.94 & 0.27 & 0.52 & 0.66 & 1.22 & 0.83 \\
\hline
\end{tabular}

$\mathrm{a}, \mathrm{b}, \mathrm{c}$ Means within the same column carrying different superscripts differ significantly $(\mathrm{P}<0.05)$

The results of hematological parameters of three strain of local chicken (Normal feather, Naked neck and Frizzled feather chicken) are presented in Table 1. The parameters considered are $\mathrm{RBC}$, WBC, $\mathrm{Hb}, \mathrm{PCV}, \mathrm{MCV}, \mathrm{MCHC}$, $\mathrm{MCH}, \mathrm{L}, \mathrm{N}, \mathrm{M}$ and $\mathrm{E}$ among the breeds. There is a significant variation in hematological parameters across breeds in PCV, HB, RBC, MCHC, and MCH in this study. The naked necked cock had the highest value in RBC ( $\mathrm{x}$ $\left.10^{9} / \mathrm{L}\right)$ and WBC $\left(\times 10^{12} / 10 \mathrm{~L}\right)$ than normal feathered and frizzle feathered cock. These results agreed with the report of Ajayi et al. (2014). Hb (g/dl) of naked neck cock indicated highest value of $12.36 \mathrm{~g} / \mathrm{dl}$, this value is higher than the result obtained by Sharmin et al. (2004). The variation in result might be due to management practice or environment which the bird are exposed to .The PCV valued $(40 \%)$ of frizzles feather cock obtained from this study revealed higher value than the result obtained by Ajayi et al.(2014) and Sharmin et al.(2004). Although the result showed no significant $(\mathrm{P}>0.05)$ different. The MCV ( fl) mean value obtained in this research is lower than the result obtained by (Ajayi et al.,2004; Sharmin et al., 2004; Iheukhthemere et al..2006). The variation might be due to season or environment. MCHC $(\mathrm{g} / \mathrm{dl})$ value obtained from this experiment agreed with Ajayi et al. ( 2014), naked necked with highest valued of 32.52 , followed by normal feathered cock and frizzle feathered cock with corresponding mean values of 31.24 and 28.47 respectively. $\mathrm{MCH}$ (pg) the mean value obtained was not significant (
P>0.05) different among the strain used for this study, although the mean value for all the breed was lower than the result obtained by Ajayi et al.(2004) and sharmin et al.(2004). The lymphocyte ( L) showed no significant different $(\mathrm{P}>0.05)$ between the normal feathered and frizzle feathered while it showed significant $(\mathrm{P}<0.05)$ different in naked necked cocks. Neutrophil $(\mathrm{N})$ of the normal feathered cock revealed the highest value followed by the frizzled feathered and naked neck cock respectively with the corresponding mean value of $30.66 \%, 30.33 \%$ and $30.00 \%$ respectively. Monocyte $(\mathrm{M})$ of the normal feathered and naked necked cock showed the highest values followed by the frizzle feathered with corresponding mean values of $10.33 \%$ and $9.33 \%$ respectively. Eiosinophil (E) of frizzle feathered and naked necked cock has the highest values of $9.33 \%$, while the normal feathered cock showed lower value of $8.33 \%$.

\section{DISCUSSION}

The haematological parameters of chicken are significance to reflect inherent genetic differences amongst the breeds of chicken (Agaie and Uko, 1998). The variation in the haematological parameters between strains in some situation might be due to season, species, immune system, and poor nutrition especially protein deficiency (Oladele $e t$ al., 2001; Adejumo, 2004). The variation in this study might be due to strains and genotype differences since all the cocks are exposed to the same environment. El-Safty $e t$ 
al. (2006) reported the superiority of the naked neck gene in PCV compared to that of the fully feathered. The author further stated that this could be a boost to the growth and productive life of the former. Haematological and serum biochemical values could be utilized in crossbreeding programmes in order to produce individuals that are fit and more productive (Ladokun et al., 2008). Genetic differences exist in all farm animals which lead to variability in the reproductive and performance abilities of animals both within, and between breeds. Differentiating this variability could be a basis for selection and subsequent genetic improvement of farm animals. Biochemical polymorphism study is one way of delineating genetic variation in animals (Egena and Aloa, 2012). This information may aid selection of superior animals within and between breeds for genetic improvement of desired traits (Bibinu et al., 2016). Since the main goal in animal breeding is to select individuals that have high breeding values for traits of interest as parents to produce the next generation and to do so as quickly as possible (Dekker, 2012). Haematological parameters might be used as a tool for selection.

\section{CONCLUSION}

The study concluded that haematogical parameters variation in this study might be due to gene in local breed of chicken. This will aid in planning breeding programme for selection of economic traits.

\section{REFERENCES}

[1] Adejumo, D.O. (2004). Haematological, growth and performance of broiler finisher fed ration supplement with Indian almond (Terminalia catappa) husk and kernel meal.

[2] Agaie, B.M. and Uko, O. (1998). Effects of season, sex and species on the packed cell volume of guinea and domestic fowls in Sokoto state of Nigeria. Nigeria Veterinary journal,19:95-99.

[3] Ajayi, F.O., Agaviezor, B. O. and Ebogomo, D. ( 2014). Comparative studies of semen and Haematology Quality of Nigeria indigenous and Exotic chicken Breeds in the Humid tropical Zone of Nigeria .G.J.B. B .Vol 3(2) 164-168.Hematological values of Broilers strain crosses ,( Ross,cobb ,Arbor acres and Arian ) International Journal .J .Poultry .Sci., 4; 573 -579.Ibadan Journal of Agricultural Research, 1 (1):1-6.

[4] Bibinu, B. S., Yakubu, A., Ugbo, S. B. and Dim, N. I. (2016). Computational Molecular Analysis of the
Sequences of BMP15 Gene of Ruminants and NonRuminants. Open Journal of Genetics, 6:39-50

[5] Dekkers, J.C.M. (2012) Application of Genomics Tools to Animal Breeding. Current Genomics, 13, 207-212.

[6] Egena, S. S. A. and Aloa, R.O. (2012). Haemoglobin polymorphism in selected farm animals-a review. Biotechnology in Animal Husbandry 30 (3): 377-390

[7] El-Safty, S.A., U.M. Ali and M.M. Fathi, (2006). Immunological parameters and laying performance of naked neck and normally feathered genotypes of chicken under winter conditions of Egypt. Int. J. Poult. Sci., 5: 780-785.

[8] Ibe, S.N. (1998). Improving productivity and adaptability of the Nigerian local chicken. Proceeding of Silver Anniv. Conference, NSAP/WASAP, University of Agriculture,Abeokuta, 21-26 March pp: 460-465.

[9] Iheukwuemere, F.C., Abu, A.H., and Ameh, M. ( 2006). Effects of Human Ganadotropin on Haematological and serum Biochemical parameters of Nigeria indigenous chickens . International Journal of Poultry Science 5 (7) 632 -634.

[10] Iheukwumere, F.C., Herbert, U. and Ewul, C. (2001). Effects of quantitative feed restriction on performance, haematology and serum biochemistry of broiler chickens, J Sustainable Trop. Agric. Res 3:56-60.

[11] Ikhimioya, Arijeniwa, 1.1, Oteku, A. and Ahmed, A. (2002).Preliminary investigation of the haematological of indigenous chicken, proceeding of the 5th Annual conference of Animal Science Association of Nigeria. September 19th-22nd, Port Harcourt, Nigeria pp:10-12.

[12] Ladokun, A. O.,Yakubu, A., J.R. Otite, J. R., Omeje, J. N., Sokunbi, O. A. and Onyeji, E. (2008). Haematological and Serum Biochemical Indices of Naked Neck and Normally Feathered Nigerian Indigenous Chickens in a Sub Humid Tropical Environment. International Journal of Poultry Science, 7 (1): 55-58

[13] Ladokun, A.O.,A. Yakubu, J.R.Otite, J.N. Omeje, O.A .Sokunbi and E.Onyeji,( 2008). Haematology and serum biochemistry indices of Naked neck and normally feathered Nigeria indigenous chickens in a sub- humid tropical environment International $\mathrm{J}$. Poultry Sci., 7;55-58

[14] Machebe, N.S. and A.G. Ezekwe, 2004. Ejaculate characteristics of three genotypes of local cocksin the 
humid tropics. J. Trop. Agric. Food, Environ.Ext., 3(2): 33-37.

[15] Melesse, A.( 2011). Performance and physiological Responses of naked neck chickens and their crosses with commercial Layer Breed to long term high Ambient Temperature. Global Veterinaria 6;272 -280

[16] Melluzzi, A., G. Primiceri, R. Giordian and G. Fabris .(1992) . Determination of blood constituents reference values in broilers Poultry Sci., 71-337 -345.

[17] NPC (2006). Nigerian population census

[18] Oladele, B.S., Ogundipe, S., Ayo, J.O. and Esievo, K.A.N. (2001). Effects of season and sex on packed cell volume,haemoglobin and total protein of indigenous pigeons in Zaria, Northern Nigeria. Veterinarski Arhiv 71(5):277-286.

[19] Pampori,Z.A . and Igbal. S. ( 2007). Heamatology, serum Chemistry and electrocardiographic evaluation in native chicken of Kashmir. International.J . Poultry Sci., 6;578 -582

[20] Sharmin , M.L., and Myemuddin , M.( 2004) . Heamatological Values of the indigenous chickens . Bangl. J. Vet. Med .2 (2) .162-164.

[21] Simaraks, S.,O.Chinrasri and Aengwanich.W.(2004).Heamatological electrolyte and Serum biochemistry value of the Thai indigenous chickens ( Gallus, domestica ) in north eastern of Thailand Songkianakarin J. Science and Technol, 26;425-430.

[22] Steel, R.D.G. and Torrie, J.H. (1980). Principles andprocedures of statistics, 2nd edition, McGraw-hill book co Inc, New York.

[23] Talebi, A.,S. Asri-Rezaei, R.Rozeb-Chai and Sahraei, R.( 2005) .Comparative studies on Haematological values of Broilers Strain ( Ross, Cobb, Arbor -acres and Arian ) International Journal .J.Poultry .Sci., 4; $573-579$. 